\title{
Cinefórum online: un experimento docente adaptado a las nuevas tecnologías de comunicación
}

\author{
E. Gavilán-Moral ${ }^{a}$, A. Villafaina-Barroso ${ }^{b}$, L. Jiménez-De Graciac ${ }^{c}$
}

La formación médica online se ha presentado como el sustituto natural de la formación presencial tradicional. Numerosas entidades proveedoras de formación, públicas o privadas, ofertan actividades en este formato. Hasta el momento, la experiencia de la docencia virtual ha ido desvelando, junto a sus ventajas, algunas limitaciones. Así, a pesar de ser un formato de indudable interés para la transmisión de conocimientos, presenta más dificultades para el aprendizaje de conductas y valores, ya que las dinámicas de grupo, la interacción entre los participantes y el fondo emocional de los contenidos, que son los que promueven los cambios de actitud, son nulos o escasos [1].

La industria del cine se ha visto atraída en múltiples ocasiones por el mundo de la salud. Son numerosos los títulos que, entre otros temas, han tratado cómo experimenta el paciente el proceso de enfermar, han abordado cuestiones bioéticas de la práctica clínica o han puesto de manifiesto la importancia de la relación entre el profesional sanitario y el paciente. Su utilidad en la formación médica es indiscutible, sobre todo por el poder de las imágenes para despertar emociones y promover debates [2]. Quizá, de todas las posibilidades docentes del cine, una de las más explotadas sea la del cinefórum [3].

La irrupción de las denominadas 'tecnologías 2.0', caracterizadas por la posibilidad de interactuar e intercambiar opiniones a través de foros y blogs, además de ver y compartir vídeos, y la incorporación de todos estos instrumentos a las plataformas virtuales de formación, dibujan un nuevo panorama en la docencia online [4]. La potencialidad de promover debates en torno a escenas de películas de temas relacionados con la salud y de poder interactuar a través de la red, permite complementar la teoría con ejercicios que se centran más en aspectos actitudinales y emocionales.

Partiendo de esta idea, pusimos en marcha durante el verano de 2009 una actividad enmarcada en un curso online ('Abordaje integral del paciente polimedicado', organizado por Unidad Editorial), consistente en la utilización, mediante un foro de acceso restringido a los inscritos en el curso, de la escena final de la película Caro diario (Nani Moretti, 1993), para fomentar discusiones en torno al fenómeno de la polimedicación. La escena describe cómo el protagonista visita distintas consultas médicas, peregrinando de especialista en especialista, con un síntoma para el cual cada facultativo prescribe una serie de medicamentos, sin llegar a analizar a fondo el problema clínico, con el consecuente uso inapropiado de medicamentos y el descontento del paciente. Insertamos las escenas de la película en el foro a través de un conocido servidor de vídeos y elaboramos un esquema de trabajo en el que se resaltaban los elementos fundamentales de cada secuencia y se lanzaban preguntas abiertas proponiendo temas de debate. Cerca de 1.200 personas visitaron el foro durante el mes que permaneció activo, generando 47 comentarios en los que se trataron temas como la ética del uso clínico del

\footnotetext{
Unidad Docente de Medicina Familiar y Comunitaria.

Servicio de Farmacia. Área de Salud Plasencia. Servicio Extremeño de Salud.

Residencia Sociosanitaria San Francisco. Servicio Extremeño de Promoción de la Autonomía y Atención a la Dependencia. Plasencia, Cáceres, España.

Correspondencia Dr. Enrique Gavilán Moral. Unidad Docente de Medicina Familiar y Comunitaria. Gerencia del Área de Salud Plasencia. Gabriel y Galán, s/n. E-10600 Plasencia (Cáceres).

Fax +34927428419

E-mail enrique.gavilan.moral@ gmail.com

Conflicto de intereses El curso'Abordaje integral del paciente polimedicado', cuyos coordinadores son los autores firmantes, fue organizado por Unidad Editorial y patrocinado por Chiesi España. Los coordinadores recibieron del organizador pagos por honorarios docentes.
} 
placebo, la importancia de la relación clínica en la adherencia terapéutica y en los resultados de la medicación, y la influencia del sistema sanitario en la prescripción facultativa. La actividad fue muy bien valorada subjetivamente por los participantes y por los coordinadores del curso.

Experiencias como ésta presentan la posibilidad de utilizar herramientas tecnológicas con fines docentes y de dotar a la formación médica online de nuevos espacios de interactividad y debate, necesarios no sólo para afianzar conocimientos, sino también para trabajar valores y actitudes.

\section{Bibliografía}

1. Grau-Perejoan O. Formación online. Educ Med 2008; 11: 139-46.

2. Icart-Isern MT, ACOPI. Metodología de la investigación y cine comercial: claves de una experiencia docente. Educ Med 2008; 11: 13-8.

3. Almendro-Padilla C, Suberviola-Collados V, Costa-Alcaraz AM. Metodología de utilización de cine-fórum como recurso docente en bioética. Tribuna Docente 2006; 8: 1-9.

4. Segura-Badía H. Las nuevas tecnologías y la formación médica continuada a distancia. Educ Med 2006; 9: 118-26. 